\title{
SISTEM PENILAIAN PRESTASI KERJA PADA PT. BANK NEGARA INDONESIA (PERSERO) TbK KANTOR CABANG SYARI'AH PEKANBARU, RIAU
}

\section{WORK ACHIEVEMENT ASSESSMENT SYSTEM IN PT. BANK NEGARA INDONESIA (PERSERO) TbK SYARI'AH BRANCH OFFICE PEKANBARU, RIAU}

\author{
Zulkifli $^{1}$, Muhammad Arif ${ }^{2}$, Ahmad Hidayatullah ${ }^{3}$ \\ Universitas Islam Riau ${ }^{1,2,3}$ \\ zulkiflirusby@,fis.uir.ac.id ${ }^{1}$
}

\begin{abstract}
Performance appraisal is a work achieved by a person in carrying out the tasks assigned to him based on skill, experience and sincerity as well as time. In this study the authors wanted to know the job performance evaluation system at PT. Bank Negara Indonesia (PERSERO) Tbk Syari'ah Pekanbaru Branch Office by focusing on 5 (five) research variables, and in this study can be seen as follows: (1) Achievement of Achievement, based on the results of processed and data analysis of respondents' answers obtained 71, 61\%. (2) Building Trust, based on the results of the processed and data analysis of respondents' answers obtained 70.31\%. (3) Focus on Customers, based on the results of processed and data analysis of respondents' answers obtained $69.27 \%$. (4) Orientation on Quality, based on the results of the processed and data analysis of respondents' answers obtained $75.78 \%$. (5) Cooperation, based on the results of the processed and data analysis of respondents' answers obtained $68.35 \%$. And in this study it can be seen that the performance appraisal system at PT. Bank Negara Indonesia (PERSERO) Tbk Syari'ah Pekanbaru Branch Office has almost reached the effective level or can be said to be "quite effective" because it is in the range of 56-76\%. This can be seen from the final results of data processing of several indicators of the existing variables of only $71.06 \%$. From the results of the questionnaire that has been analyzed.
\end{abstract}

Keywords: Assessment System, Job Performance, Islamic Banks

\begin{abstract}
ABSTRAK
Penilaian prestasi kerja adalah Suatu hasil kerja yang dicapai seseorang dalam melaksanakan tugas-tugas yang dibebankan kepadanya yang didasarkan atas kecakapan, pengalaman dan kesungguhan serta waktu. Dalam penelitian ini penulis ingin mengetahui sistem penilaian prestasi kerja pada PT. Bank Negara Indonesia (PERSERO) Tbk Kantor Cabang Syari'ah Pekanbaru dengan menfokuskan kepada 5 (lima) variabel penelitian, dan dalam penelitian ini dapat dilihat sebagai berikut : (1) Dorongan Berprestasi, berdasarkan hasil dari olahan dan analisa data jawaban responden diperoleh $71,61 \%$. (2) Membangun Kepercayaan, berdasarkan hasil dari olahan dan analisa data jawaban responden diperoleh 70,31\%. (3) Fokus Pada Pelanggan, berdasarkan hasil dari olahan dan analisa data jawaban responden diperoleh 69,27\%. (4) Orientasi Pada Kualitas, berdasarkan hasil dari olahan dan analisa data jawaban responden diperoleh 75,78\%. (5) Kerjasama, berdasarkan hasil dari olahan dan
\end{abstract}


analisa data jawaban responden diperoleh $68,35 \%$. Dan dalam penelitian ini dapat dilihat bahwa system penilaian prestasi kerja pada PT. Bank Negara Indonesia (PERSERO) Tbk Kantor Cabang Syari'ah Pekanbaru hampir mencapai tingkat efektif atau bisa juga dikatakan "cukup efektif" karena berada pada kisaran 56-76\%. Hal ini terlihat dari hasil akhir pengolahan data beberapa indikator dari varibel yang ada hanya sebesar 71,06\%. Dari hasil angket yang telah dianalisis.

Kata Kunci : Sistem Penilaian, Prestasi Kerja, Bank Syariah

PENDAHULUAN

Manajemen dalam Islam adalah sebagai alat untuk mewujudkan tujuan umum. Oleh sebab itu dikatakan bahwa manajemen dalam Islam itu adalah suatu kegiatan khusus mengenai kepemimpinan, pengarahan, pengembangan personal, perencanaan, dan pengawasan terhadap pekerjaanpekerjaan yang berhubungan dengan unsur-unsur pokok dalam suatu proyek. Tujuannya adalah supaya hasil-hasil yang ditargetkan dapat digapai dengan cara yang efektif dan efesien.

Kerja atau amal menurut Islam dapat didefenisikan dengan arti yang umum dan makna yang khusus. Amal dengan arti umum ialah melakukakan apa pun perbuatan yang disuruh atau tidak diperbolehkan oleh agama yang meliputi perbuatan baik atau buruk. Perbuatan baik dinamakan amal shaleh dan perbuatan buruk dinamakan maksiat.

Islam melihat bahwa ilmu adalah dasar penentuan harkat dan martabat seorang dalam kehidupan. Allah memerintahkan kepada RasulNya agar senantiasa memohon tambahan ilmu. Dengan bertambahnya ilmu, akan meningkatkan pengetahuan seorang muslim terhadap berbagai bagian kehidupan, baik urusan dunia atau agama. Sehingga akan mendekatkan diri dan lebih mengenal Allah, serta meningkatkan kemampuan dan kompetensinya dalam menjalankan tugas pekerjaan yang dibebankan kepadanya.
Penilaian prestasi kerja merupakan hal yang sangat penting dan hal ini perlu dan mutlak dilakukan. Kemutlakan itu terlihat jelas pada berbagai manfaat yang dapat dipetik dari padanya, baik bagi perusahaan, bagi para karyawan maupun bagi pertumbuhan dan pemiliharaan hubungan serasi antara berbagai kelompok kerja dalam suatu perusahaan atau instansi (Rokhmawati, 2013). Hal ini mengingat bahwa dalam kehidupan organisasi setiap orang sumber daya manusia dalam organisasi ingin mendapatkan penghargaan dan perlakuan yang adil dari pemimpin organisasi yang bersangkutan.

Islam telah menggariskan langkah-langkah yang sesuai yang perlu diambil dalam usaha untuk memperbaiki kelemahan, membangun dan mengembangkan pengetahuan, kemahiran dan kebolehan pekerja hasil dari pada penilaian prestasi kerja karyawan tersebut. Penentu kriteria dan kaedah penilaian prestasi kerja yang berkesan perlu diberi keutamaan karena dapat memberikan pengaruh langsung terhadap pelaksanaan aktivitas-aktivitas pengembangan sumber daya manusia dalam suatu organisasi yang lainnya seperti pengambilan keputusan dalam perekrutan karyawan, pelatihan dan pengembangan, aktivitas penilaian prestasi kerja ini perlu terus dikaji dan ditingkatkan. Tindakan ini perlu diambil untuk memenuhi tuntutan supaya hubungan antara pekerja dan organisasi dapat harmonis. 
Terlepas dari kerumitan hakikat dan keanekaragaman berbagai program pelatihan dan pendidikan, sebagian besar pengembangan terjadi di tempat kerja. Tetapi pengembangan semacam itu lambat dan kurang efektif jika karyawan tidak dinilai dan tidak diberi umpan balik secara sistematik dengan informasi yang berhubungan dengan mutu prestasinya. Semua karyawan dinilai sesuai prestasi kerja mereka dalam berbagai cara. Pada umumnya, dapat disimpulkan bahwa pilihan terletak diantara tiga kemungkinan pendekatan : (1) Penilaian sambil lalu, tidak sistematik, dan seringkali serampangan. (2) Pengukuran yang tradisional dan sangat sistematik atas : sifat-sifat karyawan, sumbangansumbangan karyawan, dan atau keduaduanya. (3) Penentuan tujuan bersama melalui suatu program Manajemen Berdasarkan Sasaran (MBS) (Yolanda et al., 2018).

Penilaian yang dirancang perusahaan sebagai alat untuk memantau pencapaian dan kemajuan perusahaan secara keseluruhan, untuk mendorong dan mendukung pengembangan sumber daya manusia yang berkelanjutan (Risho \& Susanti 2019).

Dalam melakukan penilaian terhadap karyawan ini biasanya perusahaan mempunyai tujuan yang jelas yaitu : (1) Untuk memantau dan pencapaian organisasi/ perusahaan secara keseluruhan. (2) Untuk mendorong dan mendukung pengembangan perusahaan secara berkelanjutan. (3) Untuk mendorong dan memotivasi para karyawan secara terus menerus guna mengembangkan keterampilan mereka.

Sedangkan keuntungan bagi perusahaan dari melakukan penilaian ini adalah : (a) Memiliki karyawan yang bermotivasi. (b) Mempunyai keterampilan yang baik dan dapat ditarik untuk memperkuat prestasinya. (c) Mampu mengetahui sebelum muncul persoalan, bagaimana mereka harus melatih dan mengembangkan para karyawan untuk mencapai tujuan perusahaan. (d) Dapat merasakan denyut jantung dalam organisasi/ perusahaan (Linawati, 2019).

Penilaian prestasi kerja ini adalah sebagai langkah administratif dan pengembangan yang diambil oleh perusahaan-perusahaan maupun organisasi, termasuk disana juga perusahaan yang berbentuk perbankan, diantaranya Bank, baik bank konvensional maupun bank yang berbentuk syari'ah.

Bank adalah badan usaha yang menghimpun dana dari masyarakat dalam bentuk simpanan dan menyalurkan kepada masyarakat dalam bentuk kredit dan/atau bentuk-betuk lainnya dalam rangka meningkatkan taraf hidup rakyat banyak (Ridho \& Susanti 2019).

Bank Syari' ah, adalah bank yang beroperasi dengan tidak mengandalkan pada bunga, dan juga disebut dengan lembaga keuangan/ perbankan yang opersional dan produknya dikembangkan berlandaskan pada Alquran dan Hadist Nabi SAW. Atau dengan kata lain, bank syari'ah tersebut adalah lembaga keuangan yang usaha pokoknya memberikan pembiayaan dan jasa-jasa lainnya dalam lalu lintas pembayaran serta peredaran uang yang pengoperasiannya disesuaikan dengan prinsip syari'at Islam.

Namun dari pada itu, Berdasarkan studi pendahuluan yang penulis lakukan, penulis menemukan bahwa system penilaian prestasi kerja yang dilakukan pada PT. Bank Negara Indonesia (PERSERO) Tbk Kantor Cabang Syari'ah Pekanbaru belumlah efektif, karena masih kurangnya 
pelayanan terhadap nasabah, semua itu bisa dilihat dari ketidaktahuan nasabah terhadap sistem-sistem yang dimiliki oleh bank BNI Syari'ah itu sendiri, sehingga nasabah merasa kecewa dan mengakibatkan nasabah enggan untuk menabung dan menginvestasikan dananya kepada bank BNI Syari'ah, mungkin itu diakibatkan oleh kurangnya perhatian pimpinan terhadap bawahannya, dan juga ada sebagian karyawan merasa tidak diberikan kepercayaan sepenuhnya oleh atasannya, serta kurangnya kerjasama baik itu sesama karyawan maupun dengan atasan sehingga karyawan tidak terlalu memperhatikan nasabahnya padahal tolak ukur dari berkembang atau tidaknya Bank tersebut tergantung kepada nasabahnya.

Dampak yang paling besar dialami bank BNI syari'ah dari kurangnya pelayanan terhadap nasabah tersebut yaitu susahnya dalam mencari nasabah baru, dan semua itu bisa dilihat dari beberapa masalah yakni setiap mahasiswa dan/atau siswa-siswa dari sekolah perbankan yang ingin melaksanakan magang atau praktek kerja lapangan di BNI Syari'ah tersebut diwajibkan menjadi nasabah, serta ketika mereka selesai melaksanakan studi magang, mereka diwajibkan lagi mencari nasabah minimal dua orang nasabah sebagai syarat untuk pengeluaran nilai magang atau praktek kerja lapangan mereka.

Penelitian ini merupakan penelusuran dari penelitian sebelumnya yang meneliti tentang analisa penempatan kerja terhadap prestasi kerja dimana diperoleh bahwa prestasi kerja karyawan bergantung kepada sistem penempatan kerja yang diterapkan pada sebuah perusahaan yang sesuai dengan kemampuan karyawan (Arif \& Ardiyan 2019). Selain itu juga kepuasan kerja berperan terhadap peningkatan prestasi kerja (Alfani \& Hamzah 2019)

\section{METODE PENELITIAN}

Jenis penelitian ini adalah deskriptif kuantitatif yang berlokasi di PT. Bank Negara Indonesia (PERSERO) Tbk Kantor Cabang Syari'ah Pekanbaru dengan 16 orang responden. Sumber data dalam penelitian ini terbagi menjadi dua yaitu

1. Data Primer. Adalah data yang berasal dari sumber pertama yang berupa kuesioner yang akan disebarkan langsung kepada pihak karyawan PT. Bank Negara Indonesia (PERSERO) Tbk Kantor Cabang Syari'ah Pekanbaru

2. Data Sekunder. Merupakan data yang telah diolah dan disiapkan oleh pihak PT. Bank Negara Indonesia (PERSERO) Tbk Kantor Cabang Syari'ah Pekanbaru, berupa data jumlah dan pendidikan terakhir karyawan, sejarah singkat perusahaan, struktur perusahaan serta aktivitas perusahaan

Sedangkan teknik yang digunakan dalam pengumpulan data pada penelitian ini berbentuk kuesioner. Yaitu suatu teknik pengumpulan data yang menggunakan daftar pertanyaan yang diajukan kepada karyawan PT. Bank Negara Indonesia (PERSERO) Tbk Kantor Cabang Syari'ah Pekanbaru.

Teknik analisis data pada penelitian ini adalah menggunakan teknik distribusi frekuensi kategorik. Yang distribusi frekuensi yang mengelompokkan datanya disusun berbentuk kata-kata atau didistribusi frekuensi yang penyatuan kelaskelasnya didasarkan pada data kategori. 
HASIL DAN PEMBAHASAN

\section{Analisa Data}

Setelah data terkumpul dan dituangkan dalam bentuk tabel kemudian dideskripsikan. Maka langkah selanjutnya adalah menganalisa data-data tentang sistem penilaian prestasi kerja karyawan yang dipergunakan pada PT. Bank Negara

Indonesia (Persero) Tbk Kantor Cabang Syari'ah Pekanbaru Propinsi Riau sesuai dengan data yang tergambar dalam tabel-tabel diatas.

Untuk lebih jelasnya berikut ini disajikan tabel rekapitulasi data hasil angket masing-masing responden dari beberapa variabel dibawah ini :

\section{Dorongan Berprestasi}

Tabel 1 Rekapitulasi Data Hasil Angket Variabel Dorongan Berprestasi

\begin{tabular}{|c|c|c|c|c|c|c|c|c|c|c|}
\hline \multirow{3}{*}{ No. } & \multicolumn{8}{|c|}{ ALTERNATIF JAWABAN } & \multirow{2}{*}{\multicolumn{2}{|c|}{ JUMLAH }} \\
\hline & \multicolumn{2}{|c|}{$\mathbf{A}$} & \multicolumn{2}{|c|}{ B } & \multicolumn{2}{|c|}{$\mathrm{C}$} & \multicolumn{2}{|c|}{ D } & & \\
\hline & $\mathbf{F}$ & $\mathbf{P}$ & $\mathbf{F}$ & $\mathbf{P}$ & $\mathbf{F}$ & $\mathbf{P}$ & $\mathbf{F}$ & $\mathbf{P}$ & $\mathbf{F}$ & $\mathbf{P}$ \\
\hline 1 & 16 & 100 & - & - & - & - & - & - & 16 & $100 \%$ \\
\hline 2 & 8 & 50 & 7 & 43,75 & 1 & 6,25 & - & - & 16 & $100 \%$ \\
\hline 3 & 3 & 18,75 & 1 & 6,25 & 1 & 6,25 & 11 & 68,75 & 16 & $100 \%$ \\
\hline 4 & 8 & 50 & 7 & 43,75 & 1 & 6,25 & - & - & 16 & $100 \%$ \\
\hline 5 & 7 & 43,75 & 4 & 25 & 1 & 6,25 & 4 & 25 & 16 & $100 \%$ \\
\hline 6 & - & - & 2 & 12,5 & 7 & 43,75 & 7 & 43,75 & 16 & $100 \%$ \\
\hline Total & 42 & 262,5 & 21 & 131,25 & 11 & 68,75 & 22 & 137,5 & 96 & $600 \%$ \\
\hline
\end{tabular}

Sumber : Data Olahan, 2009

Selanjutnya untuk memberi penilaian terhadap jawaban diberi skor sebagai berikut : (1) Alternatif jawaban A diberi skor 4, (2) Alternatif jawaban B diberi skor 3, (3) Alternatif jawaban C diberi skor 2, (4) Alternatif jawaban D diberi skor 1

Berdasarkan skor tersebut dapat dinilai secara keseluruhan hasil rekapitulasi dari tabel diatas, maka diperoleh angka persentase masingmasing hasil angket sebagai berikut :

$$
\begin{aligned}
& \text { - } \quad \text { Alternatif jawaban } \mathrm{A}=4 \times 42 \\
& =168 \\
& \text { - } \quad \text { Alternatif jawaban B }=3 \times 21 \\
& =63 \\
& \text { - } \quad \text { Alternatif jawaban } \mathrm{C}=2 \times 11 \\
& =22 \\
& \text { - } \quad \text { Alternatif jawaban D }=1 \times 22 \\
& =22 \\
& =96=275
\end{aligned}
$$

Rekapitulasi tersebut diolah dengan menggunakan skala likert, yaitu dengan memberikan bobot pada setiap alternatif jawaban diketahui dengan rumus sebagai berikut :

$$
\begin{aligned}
& \mathrm{P}=\frac{F}{N} \times 100 \% \\
& \text { Diketahui bahwa : } \\
& \mathrm{F}=275 \\
& \mathrm{~N}=94 \times 4=384 \\
& \text { Maka } \mathrm{P}=\frac{275}{384} \times 100 \% \\
& \quad=\underline{71,61 \%}
\end{aligned}
$$

Maka dapat diketahui variabel bahwa dorongan berprestasi dari jawaban responden dengan beberapa indikator bisa dikatakan cukup efektif karena berada pada kisaran 56\% - 75\% yaitu $71,61 \%$ 


\section{Membangun Kepercayaan}

Tabel 2 Rekapitulasi Data Hasil Angket Variabel Membangun Kepercayaan

\begin{tabular}{|c|c|c|c|c|c|c|c|c|c|c|}
\hline \multirow{3}{*}{ No. } & \multicolumn{8}{|c|}{ ALTERNATIF JAWABAN } & \multirow{2}{*}{\multicolumn{2}{|c|}{ JUMLAH }} \\
\hline & \multicolumn{2}{|c|}{$\mathbf{A}$} & \multicolumn{2}{|c|}{ B } & \multicolumn{2}{|c|}{$\mathrm{C}$} & \multicolumn{2}{|c|}{ D } & & \\
\hline & $\mathbf{F}$ & $\mathbf{P}$ & $\mathbf{F}$ & $\mathbf{P}$ & $\mathbf{F}$ & $\mathbf{P}$ & $\mathbf{F}$ & $\mathbf{P}$ & $\mathbf{F}$ & $\mathbf{P}$ \\
\hline 1 & 1 & 6,25 & 8 & 50 & 5 & 31,25 & 2 & 12,5 & 16 & $100 \%$ \\
\hline 2 & - & - & 12 & 75 & 4 & 25 & - & - & 16 & $100 \%$ \\
\hline 3 & 2 & 12,5 & 8 & 50 & 6 & 37,5 & - & - & 16 & $100 \%$ \\
\hline 4 & 6 & 37,5 & 8 & 50 & 2 & 12,5 & - & - & 16 & $100 \%$ \\
\hline Total & 9 & 56,25 & 36 & 225 & 17 & 106,25 & 2 & 12,5 & 64 & $400 \%$ \\
\hline
\end{tabular}

Selanjutnya untuk memberi penilaian maka diperoleh angka persentase masing-masing hasil angket sebagai berikut :

- Alternatif jawaban $\mathrm{A}=4 \times 9=$ 36

- Alternatif jawaban $\mathrm{B}=3 \times 36=$ 108

- Alternatif jawaban $\mathrm{C}=2 \times 17=$ 34

- Alternatif jawaban $\mathrm{D}=1 \times 2=$ 2

Jumlah

$$
=64=180
$$

Jadi diketahui bahwa :

$$
\begin{gathered}
\mathrm{F}=180 \quad \mathrm{~N}=64 \times 4=256 \\
\text { Maka } \mathrm{P}=\frac{180}{256} \times 100 \% \\
=70,31 \%
\end{gathered}
$$

Maka dapat diketahui bahwa variabel membangun kepercayaan dari jawaban responden dengan beberapa indikator bisa dikatakan cukup efektif karena berada pada kisaran $56 \%-75 \%$

\begin{tabular}{|c|c|c|c|c|c|c|c|c|c|c|}
\hline \multirow{3}{*}{ No. } & \multicolumn{8}{|c|}{ ALTERNATIF JAWABAN } & \multirow{2}{*}{\multicolumn{2}{|c|}{ JUMLAH }} \\
\hline & \multicolumn{2}{|c|}{$\mathbf{A}$} & \multicolumn{2}{|c|}{ B } & \multicolumn{2}{|c|}{$\mathrm{C}$} & \multicolumn{2}{|c|}{ D } & & \\
\hline & $\mathbf{F}$ & $\mathbf{P}$ & $\mathbf{F}$ & $\mathbf{P}$ & $\mathbf{F}$ & $\mathbf{P}$ & $\mathbf{F}$ & $\mathbf{P}$ & $\mathbf{F}$ & $\mathbf{P}$ \\
\hline 1 & 2 & 12,5 & 10 & 62,5 & 4 & 25 & - & - & 16 & $100 \%$ \\
\hline 2 & 1 & 6,25 & 6 & 37,5 & 9 & 56,25 & - & - & 16 & $100 \%$ \\
\hline 3 & 3 & 18,75 & 9 & 56,25 & 4 & 25 & - & - & 16 & $100 \%$ \\
\hline Total & 6 & 37,5 & 25 & 156,25 & 17 & 106,25 & - & - & 48 & $300 \%$ \\
\hline
\end{tabular}
yaitu $70,31 \%$.

\section{Fokus Pada Pelanggan}

Tabel 3 Rekapitulasi Data Hasil Angket Variabel Fokus Pada Pelanggan

Sumber : Data Olahan, 2019

Selanjutnya untuk memberi penilaian maka diperoleh angka persentase masing-masing hasil angket sebagai berikut :

- Alternatif jawaban $A=4 \times 6=24$

- Alternatif jawaban $B=3 \times 25=75$

- Alternatif jawaban $C=2 \times 17=34$

- Alternatif jawaban $\mathrm{D}=1 \times 1 \times 0$
Jumlah $=48=133$

Jadi diketahui bahwa :

$\mathrm{F}=133$

$\mathrm{N}=48 \times 4=192$

133

Maka $\mathrm{P}=\stackrel{133}{\mathrm{X}} 100 \%$

192

$=\underline{69,27 \%}$ 
Maka dapat diketahui bahwa variabel fokus pada pelanggan dari jawaban responden dengan beberapa indikator bisa dikatakan cukup efektif karena berada pada kisaran $56 \%-75 \%$ yaitu $69,27 \%$.

\section{Orientasi Pada Kualitas}

Tabel 4 Rekapitulasi Data Hasil Angket Variabel Orientasi Pada Kualitas

\begin{tabular}{|c|c|c|c|c|c|c|c|c|c|c|}
\hline \multirow{3}{*}{ No. } & \multicolumn{8}{|c|}{ ALTERNATIF JAWABAN } & \multirow{2}{*}{\multicolumn{2}{|c|}{ JUMLAH }} \\
\hline & \multicolumn{2}{|c|}{$\mathbf{A}$} & \multicolumn{2}{|c|}{ B } & \multicolumn{2}{|c|}{$\mathrm{C}$} & \multicolumn{2}{|c|}{ D } & & \\
\hline & $\mathbf{F}$ & $\mathbf{P}$ & $\mathbf{F}$ & $\mathbf{P}$ & $\mathbf{F}$ & $\mathbf{P}$ & $\mathbf{F}$ & $\mathbf{P}$ & $\mathbf{F}$ & $\mathbf{P}$ \\
\hline 1 & 5 & 31,25 & 8 & 50 & 3 & 18,75 & - & - & 16 & $100 \%$ \\
\hline 2 & 3 & 18,75 & 6 & 37,5 & 7 & 43,75 & - & - & 16 & $100 \%$ \\
\hline 3 & 6 & 37,5 & 5 & 31,25 & 5 & 31,25 & - & - & 16 & $100 \%$ \\
\hline 4 & 4 & 25 & 11 & 68,75 & 1 & 6,25 & - & - & 16 & $100 \%$ \\
\hline Total & 18 & 112,5 & 30 & 187,5 & 16 & 100 & - & - & 64 & $400 \%$ \\
\hline
\end{tabular}

Sumber : Data Olahan, 2019

Selanjutnya untuk memberi penilaian maka diperoleh angka persentase masing-masing hasil angket sebagai berikut :

- Alternatif jawaban $A=4 \times 18=72$

- Alternatif jawaban $B=3 \times 30=90$

- Alternatif jawaban $C=2 \times 16=32$

- Alternatif jawaban $\mathrm{D}=1 \times 0=0$

Jumlah $=64=194$

Jadi diketahui bahwa :

$\mathrm{F}=194$

$\mathrm{N}=64 \times 4=256$
194

$$
\begin{aligned}
\text { Maka P } & =\frac{194}{256} \times 100 \% \\
& =\underline{75,78 \%}
\end{aligned}
$$

Maka dapat diketahui bahwa variabel orientasi pada kualitas dari jawaban responden dengan beberapa indikator bisa dikatakan efektif karena berada pada kisaran $56 \%-75 \%$ yaitu $75,78 \%$.

\section{Kerjasama}

\begin{tabular}{|c|c|c|c|c|c|c|c|c|c|c|}
\hline \multirow{3}{*}{ No. } & \multicolumn{8}{|c|}{ ALTERNATIF JAWABAN } & \multirow{2}{*}{\multicolumn{2}{|c|}{ JUMLAH }} \\
\hline & \multicolumn{2}{|c|}{$\mathbf{A}$} & \multicolumn{2}{|c|}{ B } & \multicolumn{2}{|c|}{$\mathrm{C}$} & \multicolumn{2}{|c|}{ D } & & \\
\hline & $\mathbf{F}$ & $\mathbf{P}$ & $\mathbf{F}$ & $\mathbf{P}$ & $\mathbf{F}$ & $\mathbf{P}$ & $\mathbf{F}$ & $\mathbf{P}$ & $\mathbf{F}$ & $\mathbf{P}$ \\
\hline 1 & - & - & 9 & 56,25 & 7 & 43,75 & - & - & 16 & $100 \%$ \\
\hline 2 & 4 & 25 & 3 & 18,75 & 9 & 56,25 & - & - & 16 & $100 \%$ \\
\hline 3 & 4 & 25 & 7 & 43,75 & 5 & 31,25 & - & - & 16 & $100 \%$ \\
\hline 4 & 3 & 18,75 & 6 & 37,5 & 7 & 43,75 & - & - & 16 & $100 \%$ \\
\hline Total & 11 & 68,75 & 25 & 156,25 & 28 & 175 & - & - & 64 & $400 \%$ \\
\hline
\end{tabular}

Tabel 5 Rekapitulasi Data Hasil Angket Variabel Kerjasama

Sumber : Data Olahan Penelitian 2009

Selanjutnya untuk memberi penilaian maka diperoleh angka persentase masing-masing hasil angket sebagai berikut :

- Alternatif jawaban $\mathrm{A}=4 \times 11=$ 44
- Alternatif jawaban B $=3$ x $25=75$

- Alternatif jawaban $\mathrm{C}=2 \times 28=$ 56

- Alternatif jawaban D $=1 \times \quad 0=$ 0 
Jumlah $=64 \quad=175$

Jadi diketahui bahwa :

$\mathrm{F}=175$

$\mathrm{N}=64 \times 4=256$

175

Maka $P=\frac{175}{256} \times 100 \%$

$=\underline{68,35 \%}$

Maka dapat diketahui bahwa variabel kerjasama dari jawaban responden dengan beberapa indikator bisa dikatakan cukup efektif karena berada pada kisaran $56 \%-75 \%$ yaitu $68,35 \%$.
Untuk mengetahui hasil analisa data secara keseluruhan dari beberapa variabel penelitian tentang sistem penilaian prestasi kerja pada PT. Bank Negara Indonesia (Persero) Tbk Kantor Cabang Syari'ah Pekanbaru Propinsi Riau yang terdiri dari beberapa indikator yaitu dengan cara menjumlahkan hasil persentase dari rekapitulasi pernyataan responden terhadap beberapa indikator tersebut selanjutnya dibagi dengan jumlah seluruh variabel penelitiannya, maka untuk lebih jelasnya dapat dilihat pada tabel berikut ini :

Tabel 6 Rekapitulasi Data Hasil Angket Secara Keseluruhan

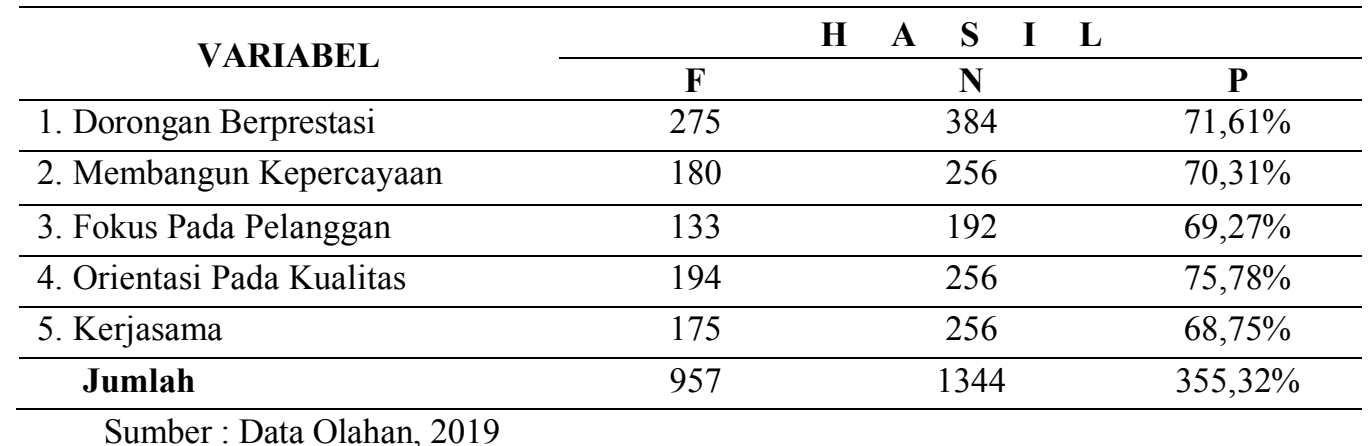

Sumber : Data Olahan, 2019

Diketahui jumlah dari hasil rekapitulasi data dari variabel-variabel penelitian ini yaitu $355,32 \%$, dan jumlah variabel dalam penelitian ini sebanyak 5 (lima) variabel, maka $355,32 \%$ dibagi 5 (lima) adalah $71,06 \%$.

Maka dapat diketahui bahwa sistem penilaian prestasi kerja pada PT. Bank Negara Indonesia (Persero) Tbk Kantor Cabang Syari'ah Pekanbaru Propinsi Riau berada pada 56\%-75\%, yaitu $71,06 \%$. Ini menandakan bahwa sistem penilaian prestasi kerja pada PT. Bank Negara Indonesia (Persero) Tbk Kantor Cabang Syari'ah Pekanbaru Propinsi Riau bisa dikatakan "Cukup Baik.

Penilaian yang dirancang
perusahaan sebagai alat untuk

memantau pencapaian dan kemajuan perusahaan secara keseluruhan, untuk mendorong dan mendukung pengembangan sumber daya manusia yang berkelanjutan (Risho \& Susanti 2019).

Penilaian prestasi kerja ini adalah sebagai langkah administratif dan pengembangan yang diambil oleh Kantor Cabang Syari'ah Pekanbaru erusahaan-perusahaan maupun organisasi, termasuk disana juga perusahaan yang berbentuk perbankan, diantaranya Bank, baik bank konvensional maupun bank yang berbentuk syari'ah. 


\section{PENUTUP}

\section{Kesimpulan}

Berdasarkan penelitian yang telah penulis lakukan, baik dari penyebaran angket maupun wawancara terhadap sebagian karyawan sebagai pelengkap data yang penulis laksanakan di PT. Bank Negara Indonesia (PERSERO) Tbk Kantor Cabang Syari'ah Pekanbaru Propinsi Riau, maka penelitian ini penulis simpulkan sebagai berikut : (1) Berdasarkan alternatif jawaban responden dapat diketahui bahwa dorongan berprestasi dalam penilaian prestasi kerja pada Bank BNI Syari'ah Cabang Pekanbaru dapat dikategorikan "Cukup Efektif" karena berada diantara $56 \%$ sampai $75 \%$ yaitu $71,61 \%$. (2) Berdasarkan alternatif jawaban responden dapat diketahui bahwa membangun kepercayaan dalam penilaian prestasi kerja pada Bank BNI Syari'ah Cabang Pekanbaru dapat dikategorikan "Cukup Efektif" karena berada diantara $56 \%$ sampai $75 \%$ yaitu $70,31 \%$. (3) Berdasarkan alternatif jawaban responden dapat diketahui bahwa fokus pada pelanggan dalam penilaian prestasi kerja pada Bank BNI Syari'ah Cabang Pekanbaru dapat dikategorikan "Cukup Efektif" karena berada diantara $56 \%$ sampai $75 \%$ yaitu 69,27 \%. (4) Berdasarkan alternatif jawaban responden dapat diketahui bahwa orientasi pada kualitas dalam penilaian prestasi kerja pada Bank BNI Syari'ah Cabang Pekanbaru dapat dikategorikan "Efektif" karena berada diantara $56 \%$ sampai $75 \%$ yaitu 75,78 $\%$ atau bisa dibulatkan menjadi 76 \%.(5) Berdasarkan alternatif jawaban responden dapat diketahui bahwa kerjasama dalam penilaian prestasi kerja pada Bank BNI Syari'ah Cabang Pekanbaru dapat dikategorikan "Cukup Efektif" karena berada diantara 56\% sampai $75 \%$ yaitu 68,35 \%. (6) Sedangkan secara keseluruhan dari beberapa variabel tentang sistem penilaian prestasi kerja pada Bank BNI Syari'ah Cabang Pekanbaru dapat dikategorikan "Cukup Efektif" karena berkisar diantara 56\% sampai $75 \%$ yaitu $71,06 \%$.

\section{Saran}

Dilihat dari beberapa variabel tersebut diatas ada perbedaan pada angka persentasenya, pada variabel fokus pada pelanggan terdapat angka $69,27 \%$. Ini menandakan bahwa fokus pada pelanggan masih lemas dan masih perlu untuk dibenahi oleh pimpinan Bank BNI Syari'ah Cabang Pekanbaru. Dan juga pada variabel kerjasama terdapat angka $68,35 \%$.

\section{DAFTAR PUSTAKA}

Arif, M., \& Ardiyan, B. (2019).

Analisis Faktor Penempatan Jabatan terhadap Prestasi Kerja Karyawan pada PT. Zaman Teknindo Pekanbaru. COSTING: Journal of Economic, Bussines and Accounting, 2(2), 302-314.

Alfani, M. H., \& Hamzah, Z. (2019). The Effect of Quality of Work Life Toward Job Performance and Work Satisfaction at Education Staff in Islamic University of Riau. Journal of Management Info, 6(1), 4-8.

Linawati, L. (2019). Penilaian Prestasi Kerja (Performance Appraisal). Investama, 3(1).

Ridho, M., \& Susanti, F. (2019). Pengaruh Stres Kerja Dan Motivasi Kerja Terhadap Kepuasan Kerja Pada Karyawan Bank Mandiri Syariah Cabang Padang. 
Rokhmawati, P. (2013). Analisis

Penilaian Prestasi Kerja

Pegawai. JDM (Jurnal

Dinamika Manajemen), 4(1).

Yolanda, A., Ranita, S. V., Idris, I., \& Nurismilida, N. (2018). Efektivitas Penilaian Prestasi Kerja Karyawan (Studi Kasus: PTPN IV (Persero)-Kebun Tinjowan Simalungun). Jurnal Bis-A: Jurnal Bisnis Administrasi, 4(2), 69-74. 